\title{
SOME INEQUALITIES INVOLVING OPERATOR MEANS AND MONOTONE CONVEX FUNCTIONS
}

\author{
JADRANKA Mićić AND HAMID REZA MORADI
}

Abstract. Utilizing the Mond-Pečarić method and the properties of operator means, we present some Ando's type inequalities. Some inequalities in the existing literature are also generalized by our results.

Mathematics subject classification (2010): 47A63, 46L05, 47A60.

Keywords and phrases: Self-adjoint operator, positive operator, positive linear mapping, monotone convex function, operator mean.

\section{REFERENCES}

[1] J. S. Aujla And H. L. VAsudeva, Inequalities involving Hadamard product and operator means, Math. Japan. 42 (1995), 265-272.

[2] T. ANDO, Concavity of certain maps on positive definite matrices and applications to Hadamard products, Linear Algebra Appl. 26 (1979), 203-241.

[3] M. D. ChOI, A Schwarz inequality for positive linear maps on $C^{*}$-algebras, Illinois J. Math. 18 (1974), 565-574.

[4] C. Davis, A Schwarz inequality for convex operator functions, Proc. Amer. Math. Soc. 8 (1957), 42-44.

[5] M. Fuji, J. MićIĆ Hot, J. PeČARIĆ AND Y. SEO, Reverse inequalities on chaotically geometric mean via Specht ratio, II, J. Inequal. Pure and Appl. Math. 4 (2) Art. 40 (2003), 1-8.

[6] T. FURUTA, Operator inequalities associated with Hölder-McCarthy and Kantorovich inequalities, J. Inequal. Appl. 2 (1998) 137-148.

[7] I. H. GÜMÜŞ, H. R. Moradi And M. SABABheh, More accurate operator means inequalities, J. Math. Anal. Appl. 465 (2018), 267-280.

[8] F. Kubo And T. Ando, Means of positive linear operators, Math. Ann. 246 (1980), 205-224.

[9] J. Mićić, J. PeČARIĆ And Y. SEO, Complementary inequalities to inequalities of Jensen and Ando based on the Mond-Pečarić method, Linear Alg. Appl. 318 (2000), 87-107.

[10] J. MićIĆ, J. PEČARIĆ AND Y. SEO, Function order of positive operators based on the Mond-Pečarić method, Linear Alg. Appl. 360 (2003), 15-34.

[11] J. MićIĆ, H. R. MoRAdi AND F. Furuichi, Choi-Davis-Jensen's inequality without convexity, J. Math. Inequal. (2018) (accepted). arXiv:1705.09784

[12] R. Mikić, J. PeČArić And I. Perić, Reverses of Ando and Davis-Choi inequality, J. Math. Ineqal. 9 (2015), 615-630.

[13] J. PEČARIĆ AND J. MIĆIĆ, Some functions reversing the order of positive operators, Linear Alg. Appl. 396 (2005), 175-187.

[14] Y. SEO, Reverses of Ando's inequality for positive linear maps, Math. Inequal. Appl. 14 (4) (2011), 905-910. 